\title{
COPYRIGHT AND INFORMATION POLICY
}

\author{
JESSICA LITMAN* \\ I \\ INTRODUCTION
}

On March 27, 1991, a unanimous Supreme Court issued its opinion in Feist Publications v. Rural Telephone Service Company, ${ }^{1}$ holding a white pages telephone directory uncopyrightable, and surprised copyright lawyers and their clients throughout the United States. The Court discarded an idiosyncratic, but unbroken line of copyright authority with the observation that the lower courts that had decided those cases "misunderstood the statute."2 A century of settled case law on copyright infringement of maps, data bases, and directories had extended de facto copyright protection to facts ${ }^{3}$ in Feist, the Supreme Court held squarely that facts could not constitutionally be the subject of copyright protection. ${ }^{4}$ The furor the case caused is curious, in the sense that copyright has in theory excluded facts from the scope of its protection since the earliest American case to address the issue. ${ }^{5}$ Black letter law on the issue is unambiguous; copyright protects expression, but not information. ${ }^{6}$

Yet copyrights have commonly been used to protect information. ${ }^{7}$ The usual expedient is to rely on the copyright protection accorded to the form in

Copyright $\odot 1992$ by Jessica Litman

- Professor of Law, Wayne State University.

I owe thanks, as always, to Jonathan Weinberg for extensive and perceptive editorial suggestions. I would also like to thank Jane Ginsburg and Avery Katz for their helpful comments, and Margaret Pittman for bringing extensive technical literature to my attention.

1. 111 S Ct 1282 (1991).

2. Id at 1291 .

3. See generally Jane C. Ginsburg, Creation and Commercial Value: Copyright Protection of Works of Information, 90 Colum L Rev 1865 (1990); Jessica Litman, The Public Domain, 39 Emory L J 965, 989. 98 (1990); William F. Patry, Copyright in Compilations of Facts (or Why the "White Pages" Are Not Copyrightable), Communications and the Law 37, 66-68 (Dec 1990) (collecting cases).

4. Feist, $111 \mathrm{~S} \mathrm{Ct}$ at 1287-89.

5. Myers $v$ Mail E Express Co., 36 Copyright Office Bulletin 478 (SDNY 1919); see also Feist, 111 $S \mathrm{Ct}$ at 1287; Litman, 39 Emory $\mathrm{L} J$ at $989-90$ (cited in note 3 ).

6. See, for example, Marshall Leaffer, Understanding Copyright Law $\$ 2.12[\mathrm{D}]$ at 53-55 (Matthew Bender, 1989); Melville Nimmer \& David Nimmer, 1 Nimmer on Copyright \& 2.11 [A] (Matthew Bender, 1990); Rochelle C. Dreyfuss, Information Products: A Challenge to Intellectual Property Theory, 20 Intl L \& Pol 897, 903-05 (1988).

7. See, for example, Ginsburg, 90 Colum L Rev at 1873-95 (cited in note 3); Litman, 39 Emory L J at 989-91 (cited in note 3); Ira Lurvey, "Verifying" from Prior Directories- "Fair Use" or Theft?, 13 Bulletin Copyright Society 271 (1967); Ray Patterson \& Craig Joyce, Monopolizing the Law: The Scope of Copyright Protection for Law Reports and Statutory Compilations, 36 UCLA L Rev 719, 720-28 (1989); Jeffrey Squires, Copyright and Compilations in the Computer Era: Old Wine in New Bottles?, 24 Bulletin Copyright Society 18, 24-46 (1976). 
which information is expressed to prohibit use of the information itself. ${ }^{8}$ Thus, West Publishing Company relied on its copyright in the arrangement of cases reported in its National Reporter System to enjoin Mead Data from including references to West's page numbers in its Lexis computer database. ${ }^{9}$ The opinion in Feist says little that explicitly eliminates such an expedient; Feist held only that copyright will not protect a compilation of facts unless the form in which those facts are expressed is itself sufficiently creative to merit copyright protection. ${ }^{10}$ The Court therefore refused to uphold the validity of a copyright in a white pages telephone directory. ${ }^{11}$ Most works embodying information are expressed in substantially more creative form than the alphabetical listings characteristic of phone books. Feist did not reach the question whether a work embodying information in sufficiently creative form could be infringed by someone who eschewed the form and appropriated only the information it expressed. But the uproar Feist inspired is not about phone books; rather, copyright proprietors are worried that their ruses for protecting information under the rubric of copyright might be undermined by an extension of Feist's reasoning. ${ }^{12}$ And so they might; and so, I would argue, they should be.

Copyright owners are understandably eager to expand the scope of their exclusive rights to encompass all valuable uses of their works. Advocates of protectionist copyright legislation have been quick to assure Congress that enhancing copyright protection will have no impact on the public's access to information or ideas, because copyright, by its nature, leaves information and ideas unprotected. ${ }^{13}$ Indeed, copyright has traditionally been viewed as a

8. See, for example, Shira Perlmutter, The Scope of Copyright in Telephone Directories: Keeping Listing Information in the Public Domain, $38 \mathrm{~J}$ Copyright Society of USA 1, 4-12 (1990). The Upjohn Company recently attempted to prevent the release of documents produced during discovery in a wrongful death suit by registering its copyright claim and then countersuing the wrongful death plaintiff for "imminent copyright infringement." The district court, however, refused to uphold Upjohn's claim, finding defects in the application for copyright registration and insufficient evidence to support Upjohn's claim of authorship. See Grundberg v Upjohn Co., Nos C89-274, C91-003g, slip op (D Utah, June 14, 1991); 42 Patent, Trademark \& Copyright J (BNA) 227 (1991). Upjohn settled the copyright claim while its appeal of the trial court's ruling was pending. See Andrew Blum, Upjohn Still Faces Halcion Suits, Natl L J 9 (Aug 26, 1991). See also Upjohn Co. v Briggs, 1:90-CV-1057 (WD Mich, 1990) (summarized in Blum, Natl L J at 9).

9. West Publishing Co. v Mead Data Central, 799 F2d 1219 (8th Cir 1986); see also Bellsouth Advertising and Publishing Corp. v Donnely Information Publishing, Inc., 933 F2d 952 (11th Cir 1991); Educational Testing Services v Katzman, 793 F2d 533 (3d Cir 1986) (copyright in Scholastic Aptitude Test questions infringed by test preparation course using questions with similar structure and content); National Business Lists, Inc. v Dun E Bradstreet, Inc., 552 F Supp 89 (ND Ill 1982) (copyright in credit reference book infringed by mailing lists including names and information gleaned from the reference book).

10. See Feist, $111 \mathrm{~S} \mathrm{Ct}$ at 1293-95.

11. Id at 1297 .

12. See, for example, Dale M. Cendali, Intellectual Property: Fact-Compilation Ruling May Hinder Protection; Copyright for Directories?, 13 Natl L J 22 (June 17, 1991); Michael Klipper \& Meredith Senter, Commentary: No Protection for "Just the Facts," The Recorder 4 (June 11, 1991); Richard Raysman \& Peter Brown, Computer Law: Supreme Court Limits Protection of Databases, NY L J 3 (May 14, 1991).

13. See, for example, Computers and Intellectual Property, Hearings before the Subcommittee on Courts, Intellectual Property, and the Administration of Justice of the House Committee on the Judiciary, 101st Cong, 1st \& 2d Sess 200-205 (1990) (testimony of Thomas M. Lemberg, Lotus Development Corp) ("Computers and Intellectual Property Hearings"). 
useful adjunct to information policy. By providing incentives to disseminate works of authorship, it promotes the marketplace of ideas. Because the rights in the copyright bundle are subject to inherent limitations, copyright leaves the ideas and information contained in the works it protects accessible to all. ${ }^{14}$ Thus, copyright has been seen as a means for encouraging learning. ${ }^{15}$ That copyright law may be developing into the engine that drives an information policy sharply restrictive of the public's access to ideas and information seems unthinkable.

There has been historic tension, however, between the desire of copyright owners to expand their rights to encompass exclusive rights to the ideas and information their works describe, and the policies dictating that ideas and information be free for others to use. ${ }^{16}$ Ideas and information, after all, can have tremendous value, and can be the source of tremendous wealth for those who can exercise control over their use. ${ }^{17}$ For these reasons, copyright proprietors have made expansive claims in court about the scope of copyright protection, ${ }^{18}$ and have lobbied Congress to repeal statutory provisions that limited copyright's scope. ${ }^{19}$

Recently, the basic principle that copyright protects neither ideas nor information has eroded, as copyright owners have found strategies to prevent the disclosure and dissemination of ideas and information that have become valuable commodities in the contemporary marketplace. ${ }^{20}$ Perhaps because of the staggering amounts of money involved in markets for ideas and information, courts and Congress lately have been markedly more receptive

14. For elaboration of this point, see, for example, Paul Goldstein, 1 Copyright $\$ 1.1$ at 4-5 (Little Brown, 1989); Jerome H. Reichman, Design Protection and the New Technologies: The United States Experience in a Transnational Perspective, 19 U Balt L Rev 6, 141-44 (1991).

15. See Goldstein, 1 Copyright $\$ 1.1$ at 4-5 (cited in note 14); L. Ray Patterson, Free Speech, Copyright, and Fair Use, 40 Vand L Rev 1, 6-7 (1987).

16. See, for example, Litman, 39 Emory L J at 977-94 (cited in note 3).

17. See, for example, Dreyfuss, 20 Intl L \& Pol at 897 (cited in note 6); Pamela Samuelson, Information as Property: Do Ruckleshaus and Carpenter Signal a Changing Direction in Intellectual Property Law?, 38 Cath U L Rev 365, 367 (1989).

18. See, for example, Litman, 39 Emory $L J$ at $983-84$ (cited in note 3 ).

19. See Jessica Litman, Copyright and Technological Change, 68 Or L Rev 275 (1989).

Courts have historically been wary of overinflating the rights in the copyright bundle. See, for example, Baker $v$ Selden, 101 US 99 (1879); Miller v Universal City Studios, Inc., 650 F2d 1365 (5th Cir 1981); Continental Casualty v Beardsley, 253 F2d 702 (2d Cir 1958); Muller $v$ Triborough Bridge Authority, 43 F Supp 298 (SDNY 1942); Brief English Systems v Owen, 48 F2d 555 (2d Cir 1931); see generally Litman, 39 Emory L J at 965 (cited in note 3).

Congress, in the past, has been similarly cautious. Among the requests unsuccessfully pressed in connection with the copyright revision effort that produced the Copyright Act of March 4, 1909,35 Stat 1075, were requests to grant copyright protection to the news of the day, and to overrule the Supreme Court's opinion in Baker v Selden, 101 US at 99. See E. Fulton Brylawski \& Abraham Goldman, The Legislative History of the 1909 Copyright Act xcvii (F.B. Rothman, 1976). Among the unsuccessful requests made in connection with the revision that culminated in the Copyright Act of 1976, Pub L No 94-553, 90 Stat 2541, codified as amended at 17 USC $\$ \S 101-810$ (1989), was a request to replace the first sale doctrine with an exclusive right of public lending. See, for example, Copyright Law Revision Part 2: Discussion and Comments on Report of the Register of Copyrights on the General Revision of the US Copyright Law, House Committee on the Judiciary, 88th Cong, 1st Sess 313 (1963) (remarks of Irwin Karp, Authors League of America).

20. See, for example, Patterson, 40 Vand L Rev at 53-63 (cited in note 15); see generally Litman, 68 Or L Rev at 275 (cited in note 19). 
to copyright owners' claims for more extensive control over the contents of their works. A tide of strong protectionism in influential commentary ${ }^{21}$ has encouraged the courts to view copyright as a broad property right. ${ }^{22}$ Meanwhile, pressures to reduce the trade deficit have encouraged Congress to accommodate the demands of intellectual property owners who succeed in linking their requests to trade and competitiveness issues. ${ }^{23}$ Feist was so surprising, not because the legal principles it announced were unprecedented, but because it bucked a pronounced trend.

One instance of this trend is the piecemeal repeal of the first sale doctrine, which has historically permitted the purchaser of a copy of a copyrighted work to sell, loan, lease, or display the copy without the copyright owner's permission, and is the reason why public libraries, video rental stores, and art galleries are not illegal. ${ }^{24}$ The first sale doctrine has thus enhanced public access to copyrighted works that some were unable to purchase. Because the first sale doctrine applies only to copies of a copyrighted work, it has become increasingly irrelevant in a world in which vast numbers of works are disseminated to the public through media that involve no transfer of copies. Copyright owners who do distribute copies of their works, however, have lobbied for the first sale doctrine's repeal. Congress yielded to the entreaties of the recording industry to limit the first sale doctrine as it applied to phonorecords in 1984. ${ }^{25}$ After the computer software industry's attempts to evade the operation of the first sale doctrine-by claiming that their

21. See, for example, Nimmer on Copyright (cited in note 6); Robert C. Denicola, Copyright in Collections of Facts: A Theory for the Protection of Nonfiction Literary Works, 81 Colum L Rev 516 (1981); Paul Goldstein, Derivative Rights and Derivative Works in Copynight, $30 \mathrm{~J}$ Copyright Society of USA 209 (1983).

22. See, for example, West Publishing Co., 799 F2d at 1223; Rockford Map Publishers, Inc. v Directory Service Co. of Colo., 768 F2d 145 (7th Cir 1985); National Business Lists, 552 F Supp 89 (ND Ill 1982); Worlds of Wonder, Inc. $v$ Veritel Learning Systems, 658 F Supp 351 (ND Tex 1986); see generally Patterson, 40 Vand L J (cited in note 15); Patterson \& Joyce, 36 UCLA L Rev at 719 (cited in note 7).

23. Thus, a century-long effort to persuade the United States to join the Berne Convention for the Protection of Literary and Artistic Works, 168 Consolidated Treaty Series 185 (1886) finally succeeded when proponents couched their arguments in the language of foreign trade. See, for example, The Berne Convention, Hearings on S 1301 and S 1971 before the Subcommittee on Patents, Copyrights and Trademarks of the Senate Committee on the Judiciary, 100th Cong, 2d Sess 1-2 (1988) (statement of Senator DeConcini); id at 41 (statement of Senator Hatch); id at 42 (statement of Senator Leahy); id at 44 (statement of Representative Kastenmeier); Marshall Leaffer, International Copyright from an American Perspective, 43 Ark L Rev 373 (1990). During the same period, industry complaints that rampant piracy was undermining American competitiveness helped persuade Congress to yield to the demands of industry representatives to limit the first sale doctrine with respect to phonorecords and computer software, and to grant copyright owners a hitherto unprecedented exclusive public lending right. See text accompanying notes 26-32. See also Industrial Design Protection, Hearings on HR 902, HR 3017 and HR 3499 before the Subcommittee on Courts, Intellectual Property, and the Administration of Justice of the House Committee on the Judiciary, 101 Cong, 2d Sess (1990).

24. See 17 USC $\$ 109$ (1989); see generally John M. Kernochan, The Distribution Right in the United States of America: Review and Reflections, 42 Vand L Rev 1407 (1989); see also Litman, 68 Or L Rev at 338-40, 351-52 n424 (cited in note 19).

25. Record Rental Amendment of 1984, Pub L No 98.450, 98 Stat 1727 (1984), codified as amended at 17 USC $\S \S 109,115$ (1989); see Kernochan, 42 Vand L Rev at 1418-20 (cited in note 24). 
distribution of software products involved licenses rather than sales ${ }^{26}$ received an unenthusiastic reception in court, ${ }^{27}$ Congress partially repealed the first sale doctrine as it applied to computer programs. ${ }^{28}$ Bills to repeal the first sale doctrine for audio/visual works have been introduced in Congress, ${ }^{29}$ but have not yet carried the day; and legislation to modify the first sale doctrine for visual art also has been at least temporarily stalled by a statute requesting the Register of Copyrights to study the issue. ${ }^{30}$ Nobody has yet introduced legislation to repeal the first sale doctrine for books. ${ }^{31}$ If, however, as some observers predict, the world moves to a regime in which the contents of books are disseminated electronically, ${ }^{32}$ such a proposal would be unnecessary.

A second instance of this trend is the current assault on the principle that works of the U.S. government are ineligible for copyright protection. ${ }^{\mathbf{3}}$ Several federal agencies have exploited statutory loopholes to acquire copyright protection, or its equivalent, for government-funded and supervised works. ${ }^{34}$ Agencies have floated proposals to establish copyright protection for federally collected data disseminated electronically. ${ }^{35}$ The current administration and the Copyright Office support legislation to repeal the prohibition of copyright in government works for computer software

26. See Pamela Samuelson, Modifying Copyrighted Software: Adjusting Copyright Doctrine to Accommodate a Technology, 28 Jurimetrics J 179, 188-89 (1988); Duncan M. Davidson, Common Law, Uncommon Software, 47 U Pitt L Rev 1037, 1053 (1986); Litman, 68 Or L Rev at 351 n424 (cited in note 19).

27. See Vault Corp. $v$ Quaid Software, Ltd., 847 F2d 255 (5th Cir 1988).

28. Computer Software Rental Amendments Act of 1990, Pub L No 101-650, 104 Stat 5089, $5134 \S \S 801-804$, codified at 17 USC $\S 109$.

29. See S 33, 98th Cong, lst Sess (Jan 25, 1983), in 129 Cong Rec 590 (Jan 26, 1983); HR 1029, 98th Cong, lst Sess (Jan 26, 1983), in 129 Cong Rec H201 (Jan 27, 1983); Home Video Recording, Hearing before the Senate Committee on the Judiciary, 99th Cong, 2d Sess (1987).

30. Visual Artists Rights Act of 1990, Pub L No 101-650, 104 Stat 5089, $5132 \S 608$.

31. Such legislation has, however, been proposed. See Kernochan, 42 Vand L Rev at 1423-30 (cited in note 24).

32. See, for example, Richard Curtis, Agent's Corner: Here Come the Cyberbooks Part 3, Locus 11 (April 1991); see also Robert W. Kastenmeier, The 1989 Horace Manges Lecture-- "Copyright in an Era of Technological Change: A Political Perspective," 14 Colum-VLA J L \& Arts 1, 20 (1989).

33. See 17 USC $\$ 105$ (1989).

34. See, for example, 48 CFR \$ 227.480 (1990); Schnapper v Foley, 667 F2d 102 (DC Cir 1981); Note, A Constitutional Analysis of Copyrighting Government-Commissioned Work, 84 Colum L Rev 425 (1984) (authored by Andrea Simon). The House Committee on Merchant Marines and Fisheries has favorably reported HR 534, 102d Cong, lst Sess (Jan 15, 1991), in 137 Cong Rec H512 (Jan 15, 1991), which directs the Federal Maritime Commission to charge royalties for use of its database of maritime tariff filings. See 137 Cong Rec H5638 (July 18, 1991) (remarks of Representative Wise); Brent Mitchell, Government Information as Revenue Source: House Panel Would Kill Boat Tax; Substitute Fee for Computer Access to Maritime Data, Washington Post Al7 (June 25, 1991). I am grateful to Maya Bernstein, Policy Analyst at the Office of Management and Budget, for bringing this legislation to my attention.

35. See Technology Transfer: Copyright Law Constrains Commercialization of Some Federal Software 35-36 (US Gen Accounting Office, 1990), reprinted in Computers and Intellectual Property Hearings at 678, 713 -14 (cited in note 13); 137 Cong Rec H5638 (remarks of Representative Wise) (cited in note 34). The National Library of Medicine does charge fees for access to Medline, its computerized medical reference system. See Larry Thompson, Doctors May Charge for Computer Searches, Washington Post Z5 (Nov 1, 1988). 
developed through government-industry collaboration. ${ }^{36}$ That legislation has been favorably reported by committees in both houses of Congress. ${ }^{37}$

A third instance of this trend is one that $I$ will explore in some detail. This is a story about a bill to correct a perceived judicial contraction in the fair use doctrine, ${ }^{38}$ and what happened to the bill on its way through congressional subcommittees.

\section{The Fair Use BilL}

On March 14, 1990, Representative Robert Kastenmeier, Chairman of the Subcommittee on Courts, Intellectual Property, and the Administration of Justice of the House Judiciary Committee, introduced HR 4263.39 The bill failed. HR 4263 was far from the only intellectual property bill introduced by Chairman Kastenmeier during the 101 st Congress, ${ }^{40}$ nor the only bill to fail of enactment. ${ }^{41}$ A revised, and many would argue improved, version of $H R$ 4263 is even now progressing through Congress. ${ }^{42}$ The new version has

36. See 137 Cong Rec S1 1216 (July 29, 1991) (remarks of Senator Rockefeller); S 1581, 102d Cong, 1st Sess (July 29, 1991); HR 191, 102d Cong, 1st Sess (Jan 3, 1991); Grundberg, 42 Patent, Trademark \& Copyright J (BNA) $291-92$ (1991).

Rising concern about the trade deficit and lagging US competitiveness have fueled a growing interest in extending the government's technology transfer apparatus to cover the copyrighting and licensing of federally produced software. Government witnesses testifying at a 1990 House panel oversight hearing agreed that a federal copyright would be an incentive to software development and would aid in dissemination of that technology from government to industry.

Grundberg, 42 Patent, Trademark \& Copyright J (BNA) at 291.

37. See Report from the Senate Committee on Commerce, Science \& Transportation on S 1581 , S Rep No 254, 102d Cong, 1st Sess (Nov 27, 1991); Report from the House Committee on Science, Space \& Technology on HR 191, HR Rep No 415, pt 1, 102d Cong, 1st Sess (1991); 43 Patent Trademark \& Copyright J (BNA) 99 (1991); 43 Patent Trademark \& Copyright J (BNA) 27 (Nov 14, $1991)$.

38. Fair use is a judicially created privilege, now codified in 17 USC $\$ 107$ (1989), to use a reasonable portion of a copyrighted work for a reasonable purpose. See generally, William F. Patry, The Fair Use Privilege in Copyright Law (Bureau of Natl Affairs, 1985); Pierre N. Leval, Toward a Fair Use Standard, 103 Harv L Rev 1105 (1990); Jessica Litman, Copyright, Compromise and Legislative History, 72 Cornell L Rev 857, 883-88, 896-99 (1987); Patterson, 40 Vand L Rev at 1 (cited in note 15); Lloyd L. Weinreb, Fair's Fair: A Comment on the Fair Use Doctrine, 103 Harv L Rev 1137 (1990).

39. See HR 4263, 101 st Cong, 2d Sess (March 14, 1990), in 136 Cong Rec H805 (March 14, $1990)$.

40. See, for example, Visual Artists Act of 1989, HR 2690, 101 st Cong, 1st Sess (June 20, 1989), enacted as amended as part of Pub L No 101-650, 104 Stat 5089, 5128 (1990); Copyright Remedy Clarification Act, HR 1131, 101 st Cong, 1 st Sess (Feb 27, 1989), enacted as amended, Pub L No 101553, 104 Stat 2749 (1990). See generally, The 101st Congress, A Review of Amendments to the Copyright Act, 37 J Copyright Society of USA 462 (1990).

41. See, for example, Unique Architectural Structures Act of 1990, HR 3991, 101st Cong, 2d Sess (Feb 7, 1990), in 136 Cong Rec H363 (Feb 7, 1990); see also The 101st Congress, $37 \mathrm{~J}$ Copyright Society of USA at 468 (cited in note 40 ).

42. S 1035, 102d Cong, Ist Sess (May 9, 1991), in 137 Cong Rec S5648 (May 9, 1991 ); 137 Cong Rec S1 1056 (July 26, 1991 ); 137 Cong Rec S13923 (1991); see also HR 2372, 102d Cong, 1st Sess (May 16, 1991); 137 Cong Rec E1821 (May 16, 1991); HR 4412, 102d Cong, 2d Sess (Mar 5, 1992); 43 Patent Trademark \& Copyright J (BNA) 407 (Mar 12, 1992). 
sailed through the Senate without opposition; ${ }^{43}$ its prospects in the House of Representatives are uncertain. ${ }^{44}$ Neither the original bill nor the revised version would work a momentous change in the law: both supporters and opponents of the legislation have been disputing atmospherics rather than substance. Nonetheless, the history of the bill thus far illustrates the pressures on copyright policymaking, the compromises that tend to be forged, and the burdens those compromises may place on our information policy.

\section{A. Background: Fair Use of Unpublished Works}

Until 1978, federal statutory copyright was not available for most unpublished works. ${ }^{45}$ Courts had created the privilege of fair use to permit some uses of works protected by federal statutory copyright. ${ }^{46}$ The question whether unpublished works, protected by state common law copyright, might also be subject to some sort of fair use privilege was one on which authors and publishers expressed a variety of views and was never resolved by the courts. ${ }^{47}$ When Congress enacted the 1976 General Revision of Copyright Law, ${ }^{48}$ it extended federal statutory copyright to works that had not been published, and subjected all copyrighted works to the fair use privilege. ${ }^{49}$ This much of the story is uncontroversial. Whether Congress intended that the fair use privilege be available for published and unpublished works on the

43. See 137 Cong Rec S13923, S13925 (Sept 27, 1991); Roger Cohen, Conflict on Unpublished Work is Resolved, NY Times B 18 col 3 (May 10, 1991); Leon Friedman, Quoting History, 252 The Nation 759, 760 (June 10, 1991); Mark Miller, Book Notes, Washington Times Fl (May 13, 1991); Patrick Leahy \& Paul Simon, The Salinger Papers, NY Times A27 col 3 (July 19, 1991) (op-ed column by two of the current bill's sponsors).

44. Legislation identical to the language passed by the Senate was introduced in the House as Title I of HR 2372, an omnibus bill containing provisions on copyright renewal and film preservation as well as the fair use amendment. After holding hearings on the fair use provisions of HR 2372, the House Subcommittee on Intellectual Property and Judicial Administration voted to delete title I from the bill. See Report from the Committee on the Judiciary on HR 2372, HR Rep No 379, 102d Cong, lst Sess (Nov 25, 1991); Copyrights: Amended Copyright, PTO Authorization Bills Approved by House Subcommittee, Daily Report for Executives (BNA) A13 (Oct 2, 1991). The House passed the amended HR 2372 on November 25, 1991. See 137 Cong Rec H11257, H11261 (Nov 25, 1991). After the Senate bill, S 1035, passed the Senate, it was reintroduced in the House and referred to the House Judiciary Committee. See 137 Cong Rec H7087 (Sept 30, 1991); 137 Cong Rec H7197 (OCt 1, 1991); 43 Patent Trademark \& Copyright J (BNA) 101 (Dec 5, 1991). On March 5, 1992, Representative Hughes introduced HR 4412, another version of the legislation with different language. HR 4412, 102d Cong, 2d Sess (Mar 5, 1992); 138 Cong Rec H1099 (Mar 5, 1992). HR 4412 was amended in committee, and favorably reported on April 30 . See note 78.

45. See, for example, Litman, 72 Cornell $\mathrm{L} \mathrm{Rev}$ at $884-85 \mathrm{n} 179$ (cited in note 38); see also text accompanying note 109.

46. See, for example, Litman, 68 Or L Rev at 340 (cited in note 19).

47. See generally Fair Use and Unpublished Works, Joint Hearing on S 2370 and HR 4263 before the Subcommittee on Patents, Copyrights and Trademarks of the Senate Committee on the Judiciary and the Subcommittee on Courts, Intellectual Property, and the Administration of Justice of the House Committee on the Judiciary, 101st Cong, 2d Sess 28-38 (1991) ("Fair Use and Unpublished Works") (prepared statement of Ralph Oman, Register of Copyrights); see also id at 12-13 (testimony of William Patry, policy planning advisor to the US Register of Copyrights).

48. 90 Stat 2541 (1976), codified as amended at 17 USC $\$ \S 101-810$ (1989).

49. 17 USC $\$ \S 102,107,301$ (1989); see, for example, Litman, 72 Cornell L Rev at 883-88, 897 (cited in note 38 ). 
same terms remains a hotly debated issue. ${ }^{50}$ Whatever Congress might be said to have intended, however, the courts soon took a hand. In 1985, the Supreme Court decided Harper $\mathcal{E}$ Row Publishers, Inc. v. Nation Enterprises. ${ }^{51}$ The majority opinion held it to be copyright infringement to summarize, paraphrase, and quote portions of former President Gerald Ford's memoirs in a news magazine article, relying heavily on the fact that the memoirs were not yet published at the time. ${ }^{52}$ In subsequent cases involving biographers' quotations from their subjects' unpublished papers, the Court of Appeals for the Second Circuit interpreted Harper $\mathcal{E}^{2}$ Row to bar fair use of unpublished works in almost all situations. ${ }^{53}$

Statutory fair use's special solicitude for unpublished works was a development of recent vintage. Although the Supreme Court's opinion in Harper $\mathcal{E}^{\circ}$ Row purported to recite the doctrine's venerable pedigree, ${ }^{54}$ the plaintiffs had brought the case as a test case, in the hope of establishing that very principle, and the Supreme Court's decision surprised many of the copyright experts who approved of it. ${ }^{55}$ The Second Circuit's expansion of the presumption against prepublication fair use caught far more onlookers by surprise. 56

The publishing community responded to these cases with alarm (some would say hysteria), and authors and publishers launched an intensive lobbying effort to overturn them. ${ }^{57}$ Representative Kastenmeier introduced

50. My own reading of the legislative history of the 1976 Act persuades me that the statute's drafters did indeed intend to subject unpublished works to the limitations set forth in the statute, including fair use, on the same terms. See Litman, 72 Cornell L Rev at 897 (cited in note 38). See also HR 4263, 101st Cong, 2d Sess (March 14, 1990), in 136 Cong Rec H806 (1990) (remarks of Representative Kastenmeier). Others have read the legislative record differently. See, for example, Fair Use and Unpublished Works at 216 (cited in note 47) (testimony of Barbara Ringer, former Register of Copyrights) ("When Congress revolutionized the US Copyright system in 1976, it subsumed common-law copyright in statutory copyright. But there was no suggestion, whatever, that the author's fundamental right of first publication was being weakened."); id at 221-23 (prepared statement of Barbara Ringer); Patry, The Fair Use Privilege at 441-47 (cited in note 38).

51. 471 US 539 (1985).

52. Id at 552-54.

53. See Salinger $v$ Random House, Inc., 811 F2d 90, 94-97 (2d Cir 1987); New Era Publications Intl $v$ Henry Holt Co., 873 F2d 576, 583-85 (2d Cir 1989), cert denied, 493 US 1094 (1990); see generally Diane Conley, Author, User, Scholar, Thief: Fair Use and Unpublished Works, 9 Cardozo Arts \& Enter L J 15 (1990); Comment, Fair Use of Unpublished Materials in the Second Circuit: The Letters of the Law, 54 Brooklyn L Rev 417 (1988) (authored by Vincent Poppe).

In a recent decision the Second Circuit upheld a finding of fair use for a biographer's "sparing" paraphrase of her subject's unpublished expression. Wright $v$ Warmer Books, Inc., 1991 US App LEXIS 28198 at $* 1$ (2d Cir, Nov 21, 1991). The court, however, noted that while there is no per se rule barring fair use of unpublished expression, the fact that the quoted or paraphrased expression was unpublished remained a significant, although not insurmountable, obstacle to a fair use defense. Id at $* 24-* 25$.

54. For a critique of the Court's analysis, see Litman, 72 Cornell L Rev at 896-97 \& n247 (cited in note 38 ).

55. See, for example, John Kernochan, Protection of Unpublished Works in the United States before and after the Nation Case, $33 \mathrm{~J}$ Copyright Society of USA 322 (1986).

56. See, for example, Comment, 54 Brooklyn L Rev at 460-63 (cited in note 53).

57. See, for example, Roger Cohen, Software Issue Kills Liberal Amendment to Copyright Laws, NY Times 1 col 1 (Oct 13, 1990); Editorial: Source Material, San Francisco Chronicle A28 (Oct 19, 1990). 
HR 4263 in response to authors' and publishers' pleas. ${ }^{58}$ Senators Paul Simon and Patrick Leahy introduced an identical companion bill two weeks later. ${ }^{59}$

\section{B. The Saga of HR 4263}

The text of HR 4263 was characterized by its supporters as elegant ${ }^{60}$ and by its detractors as vague. ${ }^{61}$ The bill, in its entirety, read:

Be it enacted by the Senate and House of Representatives of the United States of America in Congress assembled,

That section 107 of title 17, United States Code, is amended by inserting "whether published or unpublished," after "fair use of a copyrighted work." 62

Representative Kastenmeier introduced the bill with a statement on the House floor that became a lightning rod for the controversy ${ }^{63}$ and may have doomed the bill as drafted:

This amendment would clarify that section 107 applies equally to unpublished as well as published works. It does not mean that all uses of unpublished works will be considered fair use, just as not all uses of published works are now considered fair use. It does, however, mean that the same guidelines, set forth in section 107 , will apply to published works and unpublished works, and that these factors apply equally to all such works. 64

Chairman Kastenmeier's suggestion that unpublished and published works should be subject to fair use on the same terms disturbed two different interest groups. First, commentators who admired the more author-oriented copyright systems of continental Europe had seized on language in Harper $E^{\circ}$ Row to support arguments for interpreting the U.S. copyright statute to protect authors' privacy and reputational interests, notwithstanding that the language they relied on had few American antecedents. ${ }^{65}$ The ongoing efforts to conform U.S. copyright law to the requirements of the Berne Convention inspired a variety of commentators to cite this as-yet scant line of case law to support arguments that the American copyright system incorporated

58. HR 4263, 101st Cong, 2d Sess (March 14, 1990), in 136 Cong Rec H805-06 (March 14, 1990); see Bill Would Apply Fair Use Equally to Unpublished and Published Works, 39 Patent, Trademark \& Copyright J (BNA) 405 (1990).

59. S 2370, 101 st Cong, 2d Sess (March 29, 1990), in 136 Cong Rec S3549 (March 29, 1990).

60. See, for example, Fair Use and Unpublished Works at 81 (cited in note 47) (testimony of Chief Judge James Oakes); id at 101 (testimony of Judge Pierre Leval).

61. See, for example, id at 314-16 (cited in note 47) (letter from Professor Jane Ginsburg).

62. HR 4263, 101 st Congress, 2d Sess (1990), reprinted in Fair Use and Unpublished Works at 9 (cited in note 47). The companion bill, $S 2370$, reprinted in id at 8 , was identical. As amended, the first sentence of section 107 would have read:

Notwithstanding the provisions of section 106, the fair use of a copyrighted work, whether published or unpublished, ... is not an infringement of copyright.

63. See, for example, Fair Use and Unpublished Works at 102 (cited in note 47) (testimony of Judge Pierre Leval); id at 147 (remarks of Representative Kastenmeier); id at 288 (letter from Irwin Karp); id at 314 (letter from Professor Jane Ginsburg).

64. HR 4263, in 136 Cong Rec at H806; see also S2370 in 136 Cong Rec at S3550 (remarks of Senator Leahy: "Thus, the same standard would apply to both published and unpublished works.")

65. See, for example, Edward Damich, The Right of Personality: A Common-Law Basis for the Protection of the Moral Rights of Authors, 23 Ga L Rev 1, 84-88, 95-96 (1988); see also Conley, 9 Cardozo Arts \& Enter L J 15 (cited in note 53) (criticizing trend). 
European sensibilities already, and could accommodate further adjustments to make U.S. law more protective of individual authors' rights without doing violence to the premises underlying the system. ${ }^{66}$

Secondly, and ultimately fatally for the bill, the statement drew concerted opposition from the owners of computer software copyrights, who had seized on a novel argument, apparently first floated by William Patry in 1985, that computer programs published in machine-readable form remained unpublished in their source code form and were therefore properly immune from reverse engineering under the guise of fair use. ${ }^{67}$ The argument gained adherents, and acquired enhanced plausibility, when software manufacturers raised it in connection with their attempts to use the GATT ${ }^{68}$ and the European Community's effort to harmonize the copyright laws of its member nations to strengthen protection of American computer programs abroad. ${ }^{69}$ The newness of the idea that publicly disseminated works might be insulated from fair use if they could be characterized as unpublished did not diminish the fervor with which its beneficiaries clung to it. By suggesting that the copyright statute be amended so that published and unpublished works would be equally susceptible to fair use, Chairman Kastenmeier threatened to take all of that away.

Thus, despite the fact that the bill had accumulated an impressive list of supporters, it drew opposition from two camps: one camp argued that the bill would undermine copyright law's protection of privacy and reputation by qualifying the author's paramount right of first publication; ${ }^{70}$ the other maintained that the bill would undermine American competitiveness by subjecting the unpublished aspects of computer software and unpublished business documents to the fair use privilege. ${ }^{71}$

The testimony offered against the legislation is instructive: opponents argued that the bill was unnecessary, because the ideas and information contained in even unpublished works remained unprotected by copyright and

66. See, for example, Berne Convention Implementation Act of 1987, Hearings on HR 1623 before the Subcommittee on Courts, Civil Liberties and the Administration of Justice of the House Committee on the Judiciary, 100th Cong, 1st \& 2d Sess 547-49 (1988) (statement of Professor Edward J Damich); Justin Hughes, The Philosophy of Intellectual Property, 77 Georgetown L J 287, 353 (1988); see also Jane Ginsburg, $A$ Tale of Two Copyrights: Literary Property in Revolutionary France and America, 64 Tulane L Rev 991, 994-95 \& n 15 (1990).

67. Patry, The Fair Use Privilege at 400-02 (cited in note 38)

68. See generally Jerome H. Reichman, Intellectual Property in International Trade: Opportunities and Risks of a GATT Connection, 22 Vand J Transnatl L 747 (1989).

69. See generally Computers and Intellectual Property Hearings at 314-16 (cited in note 13) (statement of Ralph Oman, Register of Copyrights); id at 217-19 (letter from Representative Kastenmeier and Representative Moorhead to Carla Hills, U.S. Trade Representative); id at 352-54 (statement of Jeffrey M. Samuels, Acting Commissioner of Patents).

70. See, for example, Fair Use and Unpublished Works at 230 (cited in note 47) (statement of Jonathan Lubell of Morrison, Cohen, Singer \& Weinstein); id at 292-93 (letter from Irwin Karp); id at 90 (testimony of Judge Roger Miner).

71. See, for example, id at 345-57 (statement of James Burger, Computer \& Business Equipment Manufacturers Assn and Software Publishers Assn); id at 278 (statement of Electronic Industries Assn; inserted in the record); id at 368-69 (letter from Donald Banner, President, Intellectual Property Owners, Inc.). 
free for anyone's appropriation without resort to the fair use privilege. ${ }^{72}$ They then argued that the bill would be pernicious, because subjecting unpublished documents to the fair use privilege posed the danger that confidential ideas and information might be subject to disclosure. ${ }^{73}$ The apparent contradiction drew nobody's attention.

Ultimately, Chairman Kastenmeier withdrew HR $4263 .{ }^{74}$ Later negotiations among members of Congress, software publishers, and $H R$ 4263's supporters produced a compromise bill, ${ }^{75}$ which its sponsors describe as restoring historians' ability to quote from unpublished source material, without undermining the copyright law's protection of privacy rights or diminishing the strict limitations on any use of unpublished portions of computer programs. ${ }^{76}$ The bill would codify the case law holding that unpublished works are not normally susceptible to the fair use privilege; that is part of the bill's opponents' price for supporting any change in the current formulation of fair use. The rest of the price is ample legislative history written to ensconce computer software at the pinnacle of works entitled to nearly unqualified copyright protection. ${ }^{77}$ Once the deal was struck, the bill passed the Senate quickly. The legislation is still pending in the House, and may yet stall there. ${ }^{78}$

72. See id at 226 (statement of Jonathan Lubell); id at 230 (statement of Jonathan Lubell); id at 90-91 (testimony of Judge Roger Miner); id at 325 (testimony of James Burger); id at 368-69 (letter from Donald Banner); id at 289-90 (letter from Irwin Karp).

73. See id at 230 (statement of Jonathan Lubell); id at 151 (testimony of Judge Roger Miner); id at 326 (testimony of James Burger); id at 368-69 (letter from Donald Banner); id at 278 (statement of Electronic Industries Association): "The EIA opposes these bills because they significantly expand the potential for the fair use of unpublished works. The net result is to impact adversely the ability to protect unpublished confidential business or technical information."

74. See 136 Cong Rec H8270 (Sept 27, 1990) (remarks of Representative Kastenmeier).

75. See S 1035, 102d Cong, 1st Sess (May 9, 1991), in 137 Cong Rec S5648-49 (May 9, 1991) (remarks of Senator Simon); id at S5649 (remarks of Senator Hatch).

76. Leahy \& Simon, The Salinger Papers at A27 (cited in note 43); see S1035, 102d Cong, 1st Sess (May 9, 1991), in 137 Cong Rec S5649 (May 9, 1991); id at S5648 (remarks of Senator Simon); id (remarks of Senator Leahy); id at S5649-50 (remarks of Senator Hatch). S1035 would add a new sentence to the end of section 107 :

The fact that a work is unpublished is an important element which tends to weigh against a finding of fair use, but shall not diminish the importance traditionally accorded to any other consideration under this section, and shall not bar a finding of fair use, if such finding is made upon full consideration of all of the above factors.

77. Toward the end of the 101 st Congress, software proprietors came forward with a legislativetext-plus-legislative-history-to-accompany-it package that they insisted be considered on a take-it-orleave-it basis, and the Copyright Office objected. Negotiations continued and the parties finally reached a compromise. See Roger Zissu, Fair Use Law Enters New Era, Natl LJ 17, 22 (June 17, 1991). Every mention of the current bill in Congress seems to include an assurance that the bill will not and is not intended to impair the strong protection given to computer software or to subject unpublished source code to fair use. See, for example, S1035, 102d Cong, 1st Sess (May 9, 1991), in 137 Cong Rec S5648-49 (remarks of Senator Simon); id at S5649 (remarks of Senator Leahy); id at S5650 (remarks of Senator Hatch); S1035, 102d Cong, lst Sess (Sept 27, 1991), in 137 Cong Rec S13924) (remarks of Senator Simon); id at S13925 (remarks of Senator Leahy); Report from the Committee on the Judiciary on the Fair Use of Public Works, S Rep No 141, 102d Cong, 1st Sess (July 8, 1991).

78. As of this writing, the bill's prospects seem entirely dependent on the efforts that its Senate sponsors and the publishing community decide to invest in the bill's support. At the October 1, 1991 markup of HR 2732, the Subcommittee voted to delete the fair use provisions from the omnibus copyright bill in the hope that a forthcoming decision from the Court of Appeals for the Second 


\section{III}

\section{Copyright as Pretext}

The legislative development of the fair use bill was molded by political reality: once the bill acquired the opposition of major software manufacturers, it could not survive in its original form. Congress, as it typically does in its crafting of copyright legislation, ${ }^{79}$ referred the matter to off-the-record negotiations among interested private parties to develop an alternative that all of them could support. ${ }^{80}$ In the ensuing negotiations, the assumptions that copyright does and should protect computer software from reverse engineering and that copyright does and should safeguard authors' privacy interests were not seriously questioned; they were conditions of the compromise that the parties were working to reach.

But both assumptions should be questioned. Software owners' claim for protection against reverse engineering seems highly questionable under current law, and unwise as a matter of policy. And it is by no means clear that current copyright law incorporates concern for privacy rights. It is even less clear that it ought to.

\section{A. Fair Use and Computer Software}

The controversy over the fair use of computer software is a dispute over the permissible means that competing software developers may employ to analyze their competitors' products. ${ }^{81}$ Computer programs are initially

Circuit would resolve matters without legislative intervention. See Copyrights: Amended Copyright PTO Authorization Bills Approved by House Subcommittee, Daily Report for Executives (BNA) at A-13 (Oct 2, 1991). That decision, Wright $v$ Wamer Books, 1991 US App LEXIS 28198 (2d Cir, Nov 21, 1991), turned out to provide a less definitive resolution than the publishing community had hoped. Although the court agreed that the case before it, involving quotation and paraphrase of minuscule amounts of unpublished expression, was the rare case in which the use of unpublished expression should qualify for the fair use privilege, the court reaffirmed its holding in earlier cases that such situations would be rare. See also note 53. In the wake of Wright, the publishing community announced its intention to pursue the legislation. See Jack Miles, Endpapers: Letters and the Law, LA Times Book Review 15 (Dec 8, 1991); Ronald Sullivan, Court Relaxes Curb on Biographers' Use of Unpublished Dala, NY Times C13 col 5 (Nov 28, 1991). Representative Hughes introduced a new version of the legislation in the House. See HR 4412, 102d Cong, 2d Sess (Mar 5, 1992); 138 Cong Rec H 1099 (Mar 5, 1992); 43 Patent Trademark \& Copyright J 407 (Mar 12, 1992). The current House Bill differs from the version passed by the Senate; it would amend section 107 by appending the following sentence: "The fact that a work is unpublished shall not itself bar a finding of fair use if such finding is made upon consideration of all the above factors." As this article went to the printer, the House Judiciary Committee approved the bill and ordered it reported. See 138 Cong Rec D478 (Apr 30, 1992). If the current bill should pass the House, Congress will still need to resolve the differences between the two versions of the legislation.

79. See Kastenmeier, 14 Colum J L \& Arts at 6-7, 12 (cited in note 32); see generally Litman, 68 Or L Rev 275 (cited in note 19); Thomas P. Olson, The Iron Law of Consensus: Congressional Responses to Proposed Copyright Reforms since the 1909 Act, $36 \mathrm{~J}$ Copyright Society of USA 109 (1989).

80. See S1035, 102d Cong, Ist Sess (May 9, 1991), in 137 Cong Rec S5648-49 (remarks of Senator Simon); HR 5498, 102d Cong, 1st Sess (Sept 27, 1990) (remarks of Representative Kastenmeier); Roger Cohen, Conflict on Unpublished Work is Resolved, NY Times B18 col 3 (May 10, 1991).

81. Because the debate is framed in terms of fair use, its resolution will also affect the methods that noncommercial software analysts, such as students, may use to study software developed by others. See Computers and Intellectual Property Hearings at 431-34 (cited in note 13) (additional 
written in human-readable language called source code. ${ }^{82}$ The source code version of the program contains code for each of the program's commands, and may also contain the author's comments and descriptions, written in English, about what portions of the code are intended to do. ${ }^{83}$ The source code must then be run through a compiler program that translates all of the commands from source code to machine-readable object code, but does not translate the non-operational English language comments. ${ }^{84}$ Programs are typically distributed to the public only in their machine readable form, ${ }^{85}$ and when the copyright owner deposits the program with the Library of Congress, it will usually deposit only identifying material, comprising fifty pages of object code. ${ }^{86}$

Software developers who wish to analyze another developer's programs, therefore, rarely have access to the source code versions of the software they wish to examine. Although they must begin their analyses with the unintelligible object code version, they have a number of analytical tools to make that job feasible. ${ }^{87}$ One such tool is the process of decompilation. Decompilation is a species of reverse engineering that involves translating the object code into human-readable form, or "pseudo source code," largely through trial and error. ${ }^{88}$ Part of the decompilation process can be computerassisted: there are, for example, disassembly programs that will translate object code into an intermediate assembly language that is more decipherable to skilled readers. ${ }^{89}$ Other computer software can assist the developer in the laborious process of translating the assembly language into pseudo source code form. ${ }^{90}$ The decompilation process does not generate source code as originally written, but rather, a plausible reconstruction of what portions of the original source code could have been. Of course, the product of such reverse engineering will include only the parts of the program that were compiled into object code in the first instance; the English language comments and descriptions were never compiled and cannot be retrieved or

statement of Gideon Frieder, Dean, Syracuse University School of Computer and Information Science).

82. See id at $\mathbf{2 7 0}$ (statement of Ralph Oman).

83. See generally Margaret L. Pittman, Software Reverse Engineering: An Overview of the Case Law (unpublished manuscript, July 24, 1991).

84. See Computers and Intellectual Property Hearings at 285 (cited in note 13) (statement of Ralph Oman, relying on Duncan Davidson, Protecting Computer Software: A Comprehensive Analysis, 1983 Ariz St L J 611, 696); Pittman, Software Reverse Engineering at 26-27 (cited in note 83).

85. See Computers and Intellectual Property Hearings at 285 (cited in note 13) (statement of Ralph Oman). Oman also notes that shareware and public domain software are more frequently distributed in source code form. Id at 308-09.

86. See id at 221 (testimony of Daniel S. Bricklin, President, Software Garden, Inc.); id at 291 (statement of Ralph Oman); 37 CFR \& 202.19(c)(5) (1991).

87. See id at 478-80 (additional statement of NCR Corp.); Pamela Samuelson, Reverse-Engineering Someone Else's Software: Is it Legal?, IEEE Software 90, 91 (Jan 1990).

88. See Computers and Intellectual Property Hearings at 284-85 (cited in note 13) (statement of Ralph Oman) (relying on William T. Lake, John H. Harwood, II \& Thomas P. Olson, Tampering with Fundamentals: A Critique of Proposed Changes in EC Software Protection, 6 Computer Lawyer 1, 3-4 (1989)).

89. See Pittman, Software Reverse Engineering at 28 (cited in note 83).

90. See Computers and Intellectual Property Hearings at 284-87 (cited in note 13) (statement of Ralph Oman). 
recreated. Pseudo source code is nonetheless a useful tool that can assist a software developer in analyzing how a computer program works.

Because decompilation involves copying the program into computer memory, translating the program, and making a copy of the resulting translation, it technically infringes the copyright owner's exclusive rights under section 106 to reproduce the work in copies and to prepare derivative works. ${ }^{91}$ Because decompilation is performed in order to analyze how a program works and to investigate the ideas, processes, and logic expressed in the program, however, the technical infringement should be a classic example of fair use. ${ }^{92}$ Ideas, processes, and logic are, after all, unprotected by copyright. ${ }^{93}$ To make them accessible, it is necessary to create a derivative work, adapting the copyrighted expression into intelligible form. ${ }^{94}$ The decompilation process is thus analogous to translating a manuscript from Japanese into English in order to read it, or transcribing a concerto from a phonorecord in order to examine its harmonic structure, both easy cases of fair use under traditional analysis. The copying and adaptation are both incidental to the effort to decipher how the computer program works and what processes and methods it employs. They are, moreover, essential steps in the analysis. ${ }^{95}$

Many software owners would nonetheless prefer that decompilation not occur, because a competitor's ability to analyze how a program works aids its ability to develop a competing product. The competing product may well infringe no copyright, notwithstanding that its design was influenced by and may incorporate the ideas and processes the earlier program employed, because copyright does not protect ideas and processes. ${ }^{96}$ The new program may nonetheless win market share away from its predecessor. The software

91. Id at 286 (statement of Ralph Oman); see also id at 76-79 (Arizona State University Center for the Study of Law, Science and Technology Conference Report).

92. See id at 76-79 (Arizona State Science and Technology Conference Report).

93. 17 USC $\$ 102(\mathrm{~b})$.

94. See Dennis S. Karjala, Copyright Protection of Computer Software in the US and Japan (part 1), 1991 EIPR 195, 199.

95. See id at 199; Samuelson, IEEE Software at 93 (cited in note 87). Under the statutory fair use factors, the purpose of the use is research and analysis, although the research often occurs in a commercial setting. See 17 USC $\$ 107(1)$. The nature of the copyrighted work is that of a functional (as distinguished from fictional) work that cannot be deciphered without translation. See $\$ 107(2)$. The owners of the copyrighted work assert that an additional feature of the work's nature is that it is unpublished. On that argument, see notes 102-07 and accompanying text. The amount used varies, but can be as much as the entire computer program. See $\$ 107(3)$. The effect of the use itself on the copyright owner's potential market is nil, unless the copyright owner is willing to release a copy of the source code for a fee. The decompiler already has a purchased copy of the program in machine readable form. Thus, the use itself in no way substitutes for one the user could otherwise purchase. See $\S 107(4)$.

The analysis made possible by the decompilation may make it feasible to develop a competing program. If that program appropriates expression from the original program, it would infringe the original program's copyright and could not rely on the fair use exception. The possibility that a use that is itself fair might make it easier to infringe at some later date, however, should not defeat the fair use privilege. See also Paul Goldstein, Copynight: 1991 Supplement \$ 5.2.1.4 at 85-91 (Little Brown, 1991) (similar analysis of fair use factors).

96. See, for example, Samuelson, IEEE Software at 95 (cited in note 87). 
owners who oppose decompilation have therefore advanced the argument that decompiling a computer program cannot be fair use. ${ }^{97}$

The first strand of this argument relies on the Supreme Court's holding that use of a copyrighted work for commercial purposes is presumptively unfair.98 Since most decompilation occurs in commercial settings, it is presumptively not fair use. ${ }^{99}$ Courts have struggled with the application of this presumption since the Court first announced it in $1984,{ }^{100}$ but at least some recent cases have upheld the fair use privilege for commercially motivated conduct. ${ }^{101}$ Thus, the fact that most decompilation takes place in connection with commercial software development should not be determinative; recent cases have tended to look closely at why defendants used the copyrighted work and what use they made of it. ${ }^{102}$

The second strand of the argument is that computer programs, even those that have been publicly distributed in the mass market, are unpublished and therefore immune from fair use. ${ }^{103}$ First, software interests argue, these programs are unpublished because copies of them are never sold to members of the public. The reason that the transaction whereby a customer pays money for a copy of a computer program and receives a copy of the computer program in return is said not to be a sale is the "shrink wrap license,"'104

97. See, for example, Victor Siber, Interpreting Reverse-Engineering Law, IEEE Software 4 (July, 1990). See also HR 2372, Hearing before the Subcommittee on Intellectual Property and Judicial Administration of the House Committee on the Judiciary, 102d Cong, 1st Sess (May 30, 1991) (statement of William Neukom, testifying for the Software Publishers Association).

98. See Harper E Row Publishers $v$ Nation Enterprises, 471 US at 562; Sony Corp. of America v Universal City Studios, Inc., 464 US 417, 451 (1984) ("every commercial use of copyrighted material is presumptively an unfair exploitation"). Although this presumption has cut back on the availability of fair use in commercial settings, see, for example, Litman, 39 Emory L J at $1006 \mathrm{n} 252$ (cited in note 3 ), it makes little sense to take it too literally. If a use does not invade one of the exclusive rights in the copyright bundle, it is non-infringing whether or not its purpose is commercial. For example, when a corporation purchases copies of a book on efficient management techniques for each of its executives, distributes the books and then holds a series of seminars to discuss incorporating the book's recommendations into its managerial routines, it is surely making use of a copyrighted work for commercial purposes, and is just as surely infringing nobody's copyright.

99. See, for example, Siber, IEEE Software at 8 (cited in note 97).

100. See, for example, Litman, $68 \mathrm{Or} \mathrm{L} \mathrm{Rev} \mathrm{at} 355$ (cited in note 19).

101. See Hustler Magazine, Inc. v Moral Majority, Inc, 796 F2d 1148, 1153 (9th Cir 1986); Fisher $v$ Dees, 794 F2d 432 (9th Cir 1986); Arica Inst., Inc. v Palmer, 761 F Supp 1056 (SD NY 1991); Acuff-Rose Music, Inc. $v$ Campbell, 754 F Supp 1150 (MD Tenn 1991); Wright $v$ Wamer Books, Inc., 748 F Supp 105 (SD NY 1990), affd, 1991 US App LEXIS 28198 (2d Cir 1991).

102. See, for example, Hustler Magazine, 796 F2d at 1153; Acuff-Rose Music, 754 F Supp at 1154-55. The fact that the decompilation process itself has no negative effect on the market for the copyrighted work, see Karjala, 1991 EIPR at 199 (cited in note 94), should defeat the commercial use presumption.

103. See Fair Use and Unpublished Works at $\mathbf{3 4 9 - 5 0}$ (cited in note 47) (statement of James $M$. Burger).

104. The West Corporation's shrink wrap license for its Westmate and Westcheck software contains the following provisions:

Notice to User: It is important that you read this document before opening the sealed package and using the enclosed software (the "Software"). By using the software, you agree to be bound by the terms of this Agreement. If you do not agree, return the Software to WSI [West Services, Inc.] and you will receive a full refund of any license fee you paid 
denominating the transaction as a license. ${ }^{105}$ The statute, however, defines "publication" as "the distribution of copies or phonorecords of a work to the public by sale or other transfer of ownership, or by rental, lease or lending." 106 As a matter of statutory construction, the shrink wrap license is unlikely to persuade a court that copies of the program have not been distributed to the public either by sale or by "rental, lease or lending." Copies of the computer programs are in the possession of members of the public through a distribution process authorized by the copyright owner. If the transfer of possession is not a sale, perhaps it is a lease or a loan, but it is surely within the statutory definition of publication.

Thus, we come to the fall-back argument that computer programs remain unpublished even after their public distribution. Since computer programs are distributed only in object code form, this argument goes, the source code form remains undistributed, and therefore unpublished. Any attempt to recreate the source code from the object code, therefore, would infringe the unpublished source code version. ${ }^{107}$ Again, however, as a matter of statutory construction, such an argument is nonsense. ${ }^{108}$ What is published, or unpublished, under the statute is the work of authorship, in this case the computer program. The fact that the program is distributed in object code copies, rather than source code copies, means only that the publicly distributed medium of fixation is machine readable rather than human-

License Grant. WSI grants User a non-exclusive, non-transferable, limited license to use the Software with compatible equipment.

...

Other Restrictions. User may not loan, lease, distribute or transfer the Software or copies thereof, nor reverse engineer or otherwise attempt to discern the source code of the Software. User agrees to notify its employees and agents who may have access to the software of the restrictions contained in this Agreement and to ensure their compliance with such restrictions.

Title. Title to the software is not transferred to user. Ownership of the enclosed copy of the Software and of copies made by User is vested in WSI, subject to the rights granted to user in this Agreement.

West Publishing Company, Westlaw Software License Agreement in Westcheck (1990).

105. The shrink wrap licenses were adopted as an initial matter in an attempt to defeat program purchasers' statutory rights under 17 USC $\$ 117$ to copy and adapt programs. These rights may be exercised only by an "owner" of a copy of a computer program. See David Rice, Licensing the Use of Computer Program Copies and the Copyright Act First Sale Doctrine, 30 Jurimetrics J 157 (Winter 1990); sources cited in note 28. One copyright owner's attempt to assert in court that the license overrode or defeated a purchaser's rights under $\$ 117$ was unsuccessful. See Vault Corp. v Quaid Software, Ltd., 847 F2d 255 (5th Cir 1988). Software copyright owners currently assert that the shrink wrap licenses are effective to preserve the contents of their publicly distributed computer programs as trade secrets, by binding purchasers to agreements not to disclose, or attempt to discover, the contents of the programs. The enforceability of shrink wrap licenses as trade secrecy agreements, however, seems questionable. See, for example, Anne Branscomb, Who Owns Creativity? Property Rights in the Information Age, Technology Review 38, 45 (May/June 1988), reprinted in Computers and Intellectual Property Hearings at 43, 48 (cited in note 13); Davidson, 47 U Pitt L Rev at 1053 (cited in note 26).

106. 17 USC $\$ 101$.

107. See note 69 and accompanying text; see also Patry, The Fair Use Privilege at $401 \mathrm{n} 215$ (cited in note 38); Computers and Intellectual Property Hearings at 289 (cited in note 13) (testimony of Ralph Oman) (summarizing argument).

108. Professor Goldstein reaches the same conclusion in the recently published 1991 supplement to his three-volume treatise. See Goldstein, Copyright: 1991 Supplement at 90 (cited in note 95). 
readable. The work is published whenever copies embodying it are distributed, and the medium of fixation is irrelevant to that. A musical work, for example, can be fixed in sheet music (human readable form) or on phonorecords (machine readable form). The musical work itself is published when either are distributed. Software owners could surely argue that the English language comments in the source code version remain unpublished, because they are never compiled into the object code version that is publicly distributed. But those comments are precisely what no process of reverse engineering could recover, because they are not embodied in the object code copy. However much of the work of authorship as is embodied in publicly distributed copies has been published under the statutory definition. And that part of the work should therefore be as subject to fair use as other published works of authorship. ${ }^{109}$

The software interests' arguments that their works should be insulated from fair use have not yet been upheld by any court. They have nonetheless proved influential to the members of Congress who have been ushering the fair use bill through the enactment process. The legislative history accompanying the fair use bill, therefore, should the bill ultimately pass, will provide potent ammunition for these arguments in future litigation.

\section{B. Copyright and Privacy}

An unintended by-product of the 1976 Copyright Act's extension of statutory copyright to works that had not been published or otherwise disseminated to the public is that it altered the traditional American intellectual property bargain, which conditioned statutory protection on making the protected work available to the public. ${ }^{110}$ Before the 1976 Act, federal copyright protection was available only for published works or works that could be publicly exploited without public distribution of copies. ${ }^{111}$ Patents were, and remain, available only on the condition that the patented invention be disclosed.112 Trademarks and service marks cannot be registered until they are publicly used.113 But the 1976 Copyright Act vests copyright protection in all copyrightable works from the moment of their

109. A variation on this argument might characterize the source code version of the work as an unpublished underlying work, and the object code version of the work as a published derivative work, by virtue of the "editorial" deletions of the English language comments and the mechanical translation from source to object code. The rejoinder to this version of the argument is that the decompilation is performed on the published object code version. Indeed, the person performing the reverse engineering has no access to the unpublished source code version of the work. If she did, she would not need to resort to the laborious decompilation process.

110. See, for example, Patterson, 40 Vand L Rev at 33, 55 (cited in note 15); Pamela Samuelson, CONTU Revisited: The Case Against Copynight Protection for Computer Programs in Machine-Readable Form, 1984 Duke L J 663, 705-27.

111. Under the 1909 Copyright Act, copyright protection was available for works published with copyright notice, and also for lectures, plays, music, motion pictures, photographs, and works of art "not reproduced for sale." See Copyright Act of March 4, 1909, ch 320, §§ 10, 12, 35 Stat 1075 , codified as amended at 17 USC $\S \S 10,12$ (1976), repealed by Pub L No 94-553, 90 Stat 2541 (1976).

112. See Patents, 35 USC $\$ \S 111,112$ (1984).

113. See Commerce and Trade, 15 USC $\S 1051(\mathrm{a})$, (d) (1976). 
creation, whether or not they are ever made public. Armed with this change in the law, some commentators argue that federal copyright now incorporates protection of privacy rights. ${ }^{114}$ The arguments have some surface appeal: if copyright protects the owner's exclusive rights in a work she chooses to withhold from public view, it must be protecting her privacy interest. Moreover, state common law copyright, which federal copyright subsumed, did share a kinship with privacy law.115 Finally, the droit morale aspects of copyright in continental European nations do incorporate protections for authors' privacy and reputational interests. The Berne Convention ${ }^{116}$ requires signatory nations to protect authors' droit morale, and the United States acceded to Berne with the representation that our laws met Berne's requirements. ${ }^{117}$

In fact, the matter is not so simple. Copyright's protection of authors' privacy interests has been largely incidental to its protection of their economic copyright interests. ${ }^{118}$ When Congress replaced state common law copyright with federal statutory copyright, it failed to signal clearly whether it meant to incorporate common law copyright's solicitude for privacy as an implicit term in an otherwise explicit and detailed statute. ${ }^{119}$ In any event, the body of state privacy law related to common law copyright remains unaffected by its sister's demise $^{120}$ and has grown and flourished in the years since the 1976 Act became effective. State privacy law remains available to any plaintiff who feels her privacy has been invaded. Finally, the moral rights required by the Berne Convention are the rights of paternity and integrity, which safeguard authors' reputational interests rather than their privacy interests. ${ }^{121}$ Although strong

114. See, for example, 1 Nimmer on Copyright at $\$ 1.10[B]$ (cited in note 6); Hughes, 77 Georgetown L J at 355-58 (cited in note 66); Comment: Salinger v. Random House: The Author's Interests in Unpublished Materials, 12 Colum-VIAA J L \& Arts 103, 126-29 (1987) (authored by Christopher Murphy). See also S Rep No 141, 102d Cong, 1st Sess 9-13 (1991) (additional remarks of Senator Hatch).

115. See, for example, Kernochan, $33 \mathrm{~J}$ Copyright Society of USA at 324-25 (cited in 55).

116. Berne Convention for the Protection of Literary and Artistic Works, article VI bis.

117. See Berne Convention Implementation Act of 1988, Pub L No 100-568, 102 Stat 2853 $\S \S 2(3), 3$ (b). For a general discussion of continental droit morale, see Damich, $23 \mathrm{Ga} L \mathrm{Rev}$ at 1 (cited in note 65).

118. See Judge Jon Newman, Copyright Law and the Protection of Privacy, 12 Colum-VLA J L \& Arts 459,469 (1988).

119. See note 50. Moreover, the cases cited for the proposition that common law copyright absolutely protected authors' privacy are largely British precedents; the American version of common law copyright showed substantially less solicitude for privacy interests. See Newman, 12 Colum-VLA J L \& Arts at 466-67 (cited in note 118); Leval, 103 Harv L Rev at 1129-30 (cited in note 38).

120. Paradoxically, the question whether state privacy law might be preempted by the copyright statute depends largely on whether copyright vindicates privacy concerns. To the extent that the rights protected by copyright and privacy converge, privacy rights might be deemed equivalent to copyright rights and vulnerable to preemption under section 301 . Thus far, however, courts have not held that traditional privacy claims (as distinguished from right of publicity claims, see Baltimore Orioles, Inc. $v$ Major League Baseball Players Assn, 805 F2d 663, 674-75 (7th Cir 1986)) are preempted by the Copyright Act. See, for example, Newman, 12 Colum-VLA J L \& Arts at 476 (cited in note 118).

121. Article VI bis of the Berne Convention requires signatory nations to give authors "the right to claim authorship" of their work and the right to "object to any distortion, mutilation, or other modification of, or other derogatory action in relation to" their work. In common copyright parlance, the first is the paternity right and the second is the integrity right. 
protection of authors' privacy rights is included within the moral rights regimes of many signatory nations, Berne itself does not expressly call for it. ${ }^{122}$

The more interesting question is the normative one: should federal copyright law incorporate protection of privacy rights? I would argue not. State privacy law has evolved its own limitations and privileges that balance citizens' rights to be let alone against competing interests; ${ }^{123}$ those limitations have little to do with the policies animating copyright law. ${ }^{124}$ Copyright's limitations, in turn, would make little sense in the realm of privacy doctrine. ${ }^{125}$ In recent years, privacy law has also acquired a significant first amendment gloss. ${ }^{126}$ Copyright law has not yet been subject to comparable first amendment restrictions. ${ }^{127}$ It is worth noting that the three court cases that inflamed the debate over fair use of unpublished works by upholding plaintiffs' claims of copyright infringement over defendants' assertion of the fair use privilege ${ }^{128}$ would have fared far less successfully had they been brought as state law privacy causes of action. In none of the three cases could the plaintiff have raised a viable privacy claim. ${ }^{129}$

122. See, for example, Kernochan, $33 \mathrm{~J}$ Copyright Society of USA at 330-31 (cited in note 55). Some opponents of the fair use bill based their argument that the bill was incompatible with the Berne Convention on the language of Berne article 10(1):

It shall be permissible to make quotations from a work which has already been lawfully made available to the public, provided that their making is compatible with fair practice, and their extent does not exceed that justified by the purpose, including quotations from newspaper articles and periodicals in the form of press summaries.

If it is permissible to quote from works that have been made available to the public, the argument goes, it must be impermissible to quote from works that have not been made publicly available. See, for example, Fair Use and Unpublished Works at 312-14 (cited in note 47) (letter from Professor Jane Ginsburg). The proponents of this argument would, I think, agree that the analysis is not quite that cut-and-dried. Article 9(2) of Berne authorizes members of the Berne Union to permit the reproduction of protected works in special cases provided that there is no conflict with the work's normal exploitation or unreasonable prejudice to the author's legitimate interests. Article 9(2) makes no mention of whether a work has been made available to the public. Given that fair use determinations are made on a case-by-case basis, and that section 107 directs courts to consider "the effect of the use upon the potential market for or value of the copyrighted work," 17 USC $\S 107(4)$, extending the fair use privilege to unpublished works seems well within the scope of the article $9(2)$ authorization.

123. See Leval, 103 Harv L Rev at $1119,1129-30$ (cited in note 38).

124. See, for example, id; Comment, 54 Brooklyn L Rev at 457-60 (cited in note 53).

125. Thus, for example, in an eloquent essay arguing that copyright law should incorporate regard for privacy rights, Judge Jon Newman of the Second Circuit argued that neither the statutory duration of the copyright term nor copyright's exclusion of facts and ideas from the umbrella of its protection should be applied in connection with protection of privacy interests. Newman, 12 ColumVLA J L \& Arts at 475-79 (cited in note 118); see also Leval, 103 Harv L Rev at 1130 (cited in note 38) ("the copyright law is grotesquely inappropriate to protect privacy and obviously was not fashioned to do so").

126. See, for example, Florida Star v B.J.F., 491 US 524 (1989); Cox Broadcasting Corp. v Cohn, 420 US 469 (1975); Time, Inc., v Hill, 385 US 374 (1967).

127. See notes $132-39$ and accompanying text.

128. Harper E' Row Publishers, Inc. v Nation Enterprises, 471 US 539 (1985); Salinger $v$ Random House, Inc., 811 F2d 90, 94-97 (2d Cir 1987); New Era Publications Intl v Henry Holt Co., 873 F2d 576, 583-85 (2d Cir 1989).

129. Harper $\mathcal{E}$ Row Publishers involved an autobiographical manuscript written by a general purpose public figure with the assistance of a ghost writer working from public government documents. The manuscript was, in fact, about to be published. Salinger involved letters written by a 
The reason the cases would have failed to secure relief under state privacy laws is that privacy doctrine balances citizens' interests in protecting intimate information from disclosure against other citizens' interests in receiving and discussing that information. No citizen's privacy interest is absolute, just as society's interest in receiving and discussing all true information is not absolute. ${ }^{130}$ Courts deciding privacy cases recognize that whenever a civil suit seeks to recover damages for or to prevent the exchange of information and ideas, the individual's interest in suppression must be weighed carefully against competing social interests in unfettered discussion. Courts deciding copyright cases, in contrast, have not acknowledged the need for a comparable balancing process.

\section{IV}

\section{Copyright and Information Policy}

\section{A. Copyright and the First Amendment}

The received wisdom about the interaction between copyright and the first amendment is that the two are not in conflict."131 Both advance "the right to speak freely and the right to refrain from speaking at all."192 Thus, enjoining a biographer from publishing a biography that quotes her subject is not a prior restraint; ${ }^{133}$ prohibiting a data base from furnishing its customers with the page numbers on which language in a legal opinion may be found raises no first amendment implications; ${ }^{134}$ prohibiting a magazine from recounting a former president's description of his official actions poses no problems for freedom of the press. ${ }^{135}$

The bromide that copyright and the first amendment do not conflict with each other is said to derive from copyright law's own solicitude for ensuring the free flow of ideas. ${ }^{136}$ That solicitude, it is said, is reflected in the principle that copyright protects only expression and leaves ideas and information free for use by others, and in copyright's fair use privilege. ${ }^{137}$ Together, the distinction between idea and expression and the fair use privilege are said to

limited purpose public figure, which had been donated to libraries and were accessible to the public and were, therefore, insufficiently "private" under New York law. Holt involved the private journals of a limited purpose public figure who was now dead and had no remaining cognizable privacy or reputational interest. See Comment, 54 Brooklyn L Rev at 433 n95, 457-60 (cited in note 53).

130. See, for example, Florida Star, 491 US 524.

131. See, for example, Goldstein, 2 Copynght $\S 10.3$ at $238-43$ (cited in note 14); Leaffer, Understanding Copyright Law $\$ 10.13$, at 315-17 (cited in note 6); Patry, The Fair Use Privilege at 461-73 (cited in note 38 ).

132. Häper EO Row Publishers, 471 US at 559, quoting Wooley v Maynard, 430 US 705, 714 (1977). See also Hughes, 77 Georgetown $\mathrm{L} J$ at 358-65 (cited in note 66) ("freedom of expression is meaningless without assurances that the expression will remain unadulterated". Id at 359 (emphasis in original)).

133. See Salinger, 811 F2d at 100; Leaffer, Understanding Copyright Law $\$ 10.13$ [A] at 316 (cited in note 6).

134. See West Publishing Co. v Mead Data Central, 799 F2d 1219, 1229 (8th Cir 1986).

135. See Harper E Row Publishers, 471 US at 560.

136. See, for example, Goldstein, 2 Copyright $\$ 10.3$ at 242 (cited in note 14).

137. See id; Harper E' Row Publishers, 471 US at 560. 
supply more than sufficient protection for first amendment values within copyright law's own internal structure. ${ }^{138}$

So, here is the box that we've built for ourselves: copyright owners have frequently relied on the copyright protection accorded to the expression in their works to try to restrict the use of the ideas and information that the works express. In recent years, copyright owners have developed increasingly clever strategies to advance those goals. In a society committed to freedom of expression and its corollary of unfettered access to ideas and information, that trend might be a cause for concern. The common wisdom, however, is that no such concern is appropriate. We do not have to worry about the use of copyright to impede the dissemination of ideas and information, it is said, because fair use is there to privilege such uses. Nor need we worry about shrinking the scope of the fair use privilege, because the idea-expression distinction ensures that ideas and information will remain in the public domain. Finally, we need not concern ourselves with the specter of copyright's restricting anyone's opportunities to exercise her freedom of expression, because the fair use privilege and the idea-expression distinction provide adequate protection for such rights.

Recent efforts to further extend the scope of copyright rights have sought to give copyright owners more meaningful protection for their statutory rights, but have inevitably involved the restriction of access to ideas and information as a byproduct. ${ }^{139}$ In the rush to enhance American competitiveness, Congress has accommodated industry coalitions and yielded to political expediency without serious consideration of the implications of restricting the public's access to the contents of copyrighted works. ${ }^{140}$ Courts, at the same time, have been increasingly receptive to copyright owners' claims to control all or nearly all uses of their works. ${ }^{141}$ Supporters of these efforts assure us that any erosion in copyright's nonprotection of ideas and information can be offset by a generous application of the fair use doctrine; 142 that constriction of the fair use privilege is not problematic because of copyright's nonprotection of ideas; ${ }^{143}$ and that the first

138. See, for example, Goldstein, 2 Copyright $\$ 10.3$ at $238-43$ (cited in note 14).

139. The amendments to the first sale doctrine, see notes 24-32 and accompanying text, for example, were intended to address the problem that modern technology made the exclusive reproduction right essentially unenforceable by preventing the commercial exploitation of the public's willingness to make unauthorized copies. The resulting laws nonetheless limit public access to the affected works.

140. Chairman Kastenmeier, in contrast to many of his colleagues, regularly questioned the first amendment implications of proposed legislation. See, for example, 136 Cong Rec H805-07 (1990) (remarks of Representative Kastenmeier); 134 Cong Rec H10419 (1988) (remarks of Representative Kastenmeier). Kastenmeier's departure from the House of Representatives leaves Congress without its leading copyright expert, and also without any member who has consistently expressed a commitment to ensuring that intellectual property laws not restrict the public's freedom of expression.

141. See, for example, Dennis Karjala, Copyright, Computer Software, and the New Protectionism, 28 Jurimetrics 33, 35, 92-99 (1987); Karjala, 1991 EIPR at $201-02$ (cited in note 94); Patterson, 40 Vand L Rev 1 (cited in note 15).

142. See, for example, Denicola, 81 Colum L Rev at 538-40 (cited in note 21).

143. See, for example, sources cited in note 72 . 
amendment interests in access to ideas and information may safely be ignored because the idea-expression distinction and the fair use doctrine are adequate to resolve any problems. ${ }^{144}$ Thus lulled, Congress and the courts have approved the chipping away of the idea-expression distinction and the fair use doctrine, in each case relying on the other legal principle to take up the slack. Meanwhile, the infrequent call for a reevaluation of the first amendmentcopyright relationship ${ }^{145}$ continues to be dismissed. ${ }^{146}$

\section{B. The Shape of the Future}

The shrinking application of the idea-expression distinction, the contraction of the fair use privilege, the partial repeal of the first sale doctrine, and the movement towards allowing the federal government to claim copyright in some of the works it produces may seem like small changes in the law. Surely, some would argue, such small steps are more than justified by the resulting strengthening of the rights in the copyright bundle, and the potential for enhanced competitiveness that might be realized. Each of these small steps, however, has taken the law in the same direction: towards more limited public access to ideas and information. To the extent that these steps reflect a trend, the course of that trend is troubling. Extrapolated into a comprehensive information policy, the trend is frightening.

We have been making information policy haphazardly, altering the copyright law in response to insular disputes and short-sighted planning. An eagerness to reduce the trade deficit has spurred enthusiasm for enacting legislation that transforms into piracy any uncompensated use of copyrighted works that could generate further revenue were it deemed infringement. Copyright owners who fear that new technologies threaten their control of their works' dissemination are learning new techniques of persuasion. Courts increasingly see uncompensated uses of copyrighted works as invasions of the rights in the copyright bundle. Fortuitous legal developments have conferred on some sectors of the information industry unintended benefits. Those sectors are clinging to their windfall protections with a tenacity that has apparently made it politically impossible to divest them. The resulting reduction in access to copyrighted works, and to the uncopyrightable ideas and information they contain, is largely an unintended, incidental effect. The curtailment of access, however, is no less real for being incidental. The blithe

144. See, for example, Goldstein, 2 Copyright $\$ 10.3$ at $242-43$ (cited in note 14).

145. See Floyd Abrams, First Amendment and Copyright: The Seventeenth Donald C. Brace Memorial Lecture, 35 J Copyright Society of USA 1 (1987); Robert Denicola, Copyright and Free Speech: Constitutional Limitations on the Protection of Expression, 67 Cal L Rev 283 (1979); Gary Francione, Facing the Nation: The Standards for Copyright, Infringement, and Fair Use of Factual Works, 134 U Pa L Rev 519, 552-53, 598 (1986); Lyman Patterson, Private Copyright and Public Communication: Free Speech Endangered, 28 Vand L Rev 1161 (1975); Alfred Yen, A First Amendment Perspective on the Idea/Expression Dichotomy and Copyright in a Work's Total Concept and Feel, 38 Emory L J 393 (1989); Note, 84 Colum L Rev 425 (1984) (cited in note 34).

146. See, for example, Goldstein, 2 Copyright $\$ 10.3$ at 238-41 (cited in note 14); Leaffer, Understanding Copyright Law $\S 10.13[\mathrm{~A}]$ at 315 (cited in note 6); Patry, The Fair Use Privilege at 461-73 (cited in note 38). 
unconcern with which we rely on copyright to promote, rather than retard, the creation and dissemination of works that embody ideas and information has become untenable.

As access to ideas and information is swept more into the realm of private control under the rubric of copyright, ideas and information increasingly become available only to those citizens who purchase access to the works that contain them. In our shortsighted accommodation of industry coalitions and political expediency, we are crafting the rules of an information society without considering whether that future is one in which we would actually like to live. Because the courts deny the presence of a copyright-first amendment clash, they have made themselves unavailable to moderate the exclusionary effects of an information policy based more and more upon conditioning access on wealth.

The trend, of course, is not irreversible. Not yet. If we take the threat seriously enough to deem it more important than short term gains in trade and competitiveness, we have a number of avenues open to us for restoring the balance between copyright and the free flow of knowledge. Most fundamentally, we could begin again to take the idea-expression distinction seriously. Codified in section 102(b), the idea-expression distinction withholds copyright protection from any "idea, procedure, process, system, method of operation, concept, principle, or discovery, regardless of the form in which it is described, explained, illustrated, or embodied . ..."147 Taking the principle seriously would mean refusing to permit a copyright owner's assertion of exclusive rights in a work's form to impede others' use of the work's contents. It would mean reviving the now moribund concept of ideaexpression merger, which privileges the use of any expression necessary to describe, explain, or use the underlying ideas, methods, systems, or facts. ${ }^{148}$ If theft of expression is required in order to use the ideas or information that expression embodies, so be it. Suppressing the use of ideas and information is not what copyright is supposed to be for.

We could reinvigorate the fair use privilege, and apply it with more generosity. We could recognize that technical infringements that are incidental to lawful uses of copyrighted works should almost always be deemed fair, 149 whether they occur in a commercial context or a nonprofit one. We could wake up to the fact that drawing fair use lines around the concept of publication makes little sense in a world in which works are publicly disseminated without the distribution of copies to the public.

147. 17 USC $\& 102$ (b).

148. See Goldstein, 1 Copyright $\$ 2.3 .2$ at 80-82 (cited in note 14). Although the defense of ideaexpression merger is theoretically available in infringement suits, the modern trend is for courts to find that no merger of idea and expression have occurred. See id; see also, for example, Kregos $v$ Associated Press, 937 F2d 700 (2d Cir 1991). But see Mason v Montgomery Data, Inc., 765 F Supp 353 (SD Tex 1991) (finding merger in case involving maps).

149. See, for example, Litman, 68 Or L Rev at 346 n396 (cited in note 19); Samuelson, IEEE Software at 96 (cited in note 87 ). 
More radically, we could devise a replacement for the first sale doctrine that could preserve the secondary market it has made possible in access to copyrighted works for those who do not or cannot purchase that access in the primary marketplace. Simply leaving the first sale doctrine alone is not enough; technology is rendering it obsolete more quickly than Congress can enact its piecemeal repeal. As works are increasingly publicly exploited without the distribution of copies, the first sale has no opportunity to come into play. If we are to recapture the enhanced access to copyrighted works that the first sale doctrine has supplied, we must develop creative approaches. ${ }^{150}$ We might assess the feasibility of new privileges ${ }^{151}$ or compulsory licenses for secondary uses of electronically disseminated works. ${ }^{152}$ Or perhaps we could stop clinging to the notion that copyright law needs no first amendment adjustment because its internal limitations ensure the broad dissemination of information and ideas, and introduce explicit first amendment limitations into copyright infringement suits.

Such suggestions may inspire howls of protest from copyright owners, the lawyers who represent them, and the majority of academics who observe the field. "The American market in copyrighted works is a success story," they may say, "don't undermine it." 153 "If you diminish the incentives to create copyrighted works," they may insist, "there will be fewer such works created, and everyone will lose out."154 And, "copyright owners should not have to subsidize the public consumption of their work. We don't require that of other property owners; we have no moral claim on copyright owners that would permit us to insist that they provide their creations for free." 155

Those arguments have force, and choosing to reject them is not costless. But choosing to embrace them and the world they would produce is not costless, either. Copyright law has always involved drawing a balance between the public's claim of access to works of authorship and the ideas and

150. As an initial step, we could restore the balance between registration of copyright claims and public disclosure by reimposing meaningful deposit requirements on works now exempt from them, including works that are disseminated in machine-readable form. See 37 CFR $\$ 202.19,202.20$, 202.21 (1990). See Samuelson, 1984 Duke L J 663 (cited in note 110).

151. We could, for example, consider a privilege to make a single copy of any work, or portion of a work, that the copyright owner distributed to one in electronic form, and allow the first sale doctrine to act on each such copy.

152. See, for example, Ginsburg, 90 Colum L Rev at 1924-36 (cited in note 3). Professor Ginsburg is a friend of mine and would be horrified at the use to which I am putting her compulsory license proposal. Ginsburg argues that the copyright statute should be amended to confer copyright protection on the factual components of informational works, and offers a compulsory license for derivative users as a device to reduce the monopoly power over information that such protection would give its beneficiaries. Ginsburg would surely insist that such a device is defensible only in exchange for the increased incentives to the creation of works that enhanced copyright protection would supply.

153. See generally Computers and Intellectual Property Hearings, at 202-08 (cited in note 13) (testimony of Thomas M. Lemberg for Software Publishers Assn).

154. See generally Goldstein, 1 Copyright $\S 1.2 .3$ at $16-20$ (cited in note 14); Beryl Jones, Copyright: Factual Compilations and the Second Circuit, 52 Brooklyn L Rev 679 (1986).

155. See generally Richard Adelstein \& Steven Perez, The Competition of Technologies in Markets for Ideas: Copyright and Fair Use in Evolutionary Perspective, 5 Intl Rev L \& Econ 209 (1985); Linda Lacey, Of Bread and Roses and Copyrights, 1989 Duke L J 1532. 
information they contain, and the copyright owner's claim to control of her work and remuneration for its use. ${ }^{156}$ When we succumb to copyright owners' demands for ever-increasing incentives, we may, in the process, radically alter that balance.

\section{$\mathrm{V}$ \\ Conclusion}

The arguments I am making are alarmist ones: I am concerned about current trends towards increasing the scope of rights in the copyright bundle. I believe that the trends I have identified have already reduced, to a measurable extent, the public's access to ideas and information embodied in copyrighted works. Extrapolating those trends into the future, I see a significant threat to our information policy.

That said, trends are often relatively short-lived. The virulent protectionism that seems to have characterized the past decade might yield in the near future to a more measured approach to copyright. The United States may rethink joining the international copyright community in the role of the biggest bully on the block once it discovers that bullying nets it little in the realm of comparative national competitiveness. ${ }^{157}$ We may realize that we are now, in essence, part of an interdependent international community; we are ourselves bound by the rules we promulgate to restrict the others. Confining the access of foreign nationals to American "know how" requires us to confine the access of American citizens as well. Attempting to retard the progress of science and the useful arts made by citizens of our trading partners commits us to retard progress in the United States by the same mechanisms.

The wisest step would be to reverse the current course of copyright expansion. The political difficulty of doing so, however, could be formidable. Copyright protection now extends to an extraordinary variety of works, including many of the products of the nation's most powerful industries. Those industries appear well satisfied with the way things have been going. It is painful to relinquish short term advantages merely because they reflect long term folly; it is doubtful that the beneficiaries of recent protectionism would volunteer to do so. Thus, the prospect that the trend will soon be reversed seems unlikely, but not inconceivable. Feist introduced a new note of lucidity into the milieu; it remains to be seen whether the courts and Congress will listen.

156. See, for example, Sony Corp. of America v Universal City Studios, 464 US 417 (1984); Intellectual Property Rights in an Age of Electronics and Information, US Congress, Office of Technology Assessment (1986); Kastenmeier, 14 Colum-VLA J L \& Arts at 5-6, 24 (cited in note 32).

157. See Reichman, 22 Vand J Transnatl $L$ at 886-91 (cited in note 68). 
